\title{
Is it the end of North-American hegemony? A structuralist perspective on Arrighi's systemic cycles of accumulation and the theory of hegemonic stability
}

\author{
É este o fim da hegemonia North-americana? Uma perspectiva \\ estruturalista sobre os ciclos sistêmicos de acumulação de \\ Arrighi e a teoria da estabilidade hegemônica
}

MARCOS VINICIUS ISAIAS MENDES****

\begin{abstract}
RESUMO: O artigo objetiva apresentar alguns aspectos do debate sobre o fim da hegemonia dos Estados Unidos, à luz das teorias dos ciclos sistêmicos de acumulação e da estabilidade hegemônica. Entre suas conclusões, o artigo demonstra que a hegemonia dos EUA está diminuindo não apenas pela emergência de novas nações poderosas, como a China, mas porque o sistema internacional, composto por novos e influentes atores, tais como corporações multinacionais, cidades globais, organizações religiosas e grupos terroristas transnacionais, está diminuindo os meios pelos quais os EUA têm exercido seu poder global desde o final da Segunda Guerra Mundial.

PALAVRAS-CHAVE: Estados Unidos; Marxismo; Teoria da Estabilidade Hegemônica; Ciclos Sistêmicos de Acumulação.
\end{abstract}

ABSTRACT: The paper aims to present some aspects of the debate about the end of the hegemony of the United States, in light of the theories of systemic cycles of accumulation and hegemonic stability. Among the conclusions, the paper shows that the North-American hegemony is diminishing not only because of the emergence of new powerful countries, such as China, but because the international system, composed by new powerful actors such as multinational corporations, global cities, religious organizations and transnational terrorist groups, is diminishing the means by which the US has exercised its global power since the mid twentieth century.

KEY-WORDS: United States; Marxism; Hegemonic Stability Theory; Systemic Cycles of Accumulation.

JEL Classification: F500.

\footnotetext{
* PhD Candidate in International Relations, Universidade de Brasilia (UnB), DF - Brasil. E-mail: mvinicius.imendes@gmail.com. Submitted: December 7, 2016; Approved: July 10, 2017.

* My thanks to the two anonymous reviewers of the Brazilian Journal of Political Economy for their comments and suggestions on the first version of this paper.
} 


\section{UNITED STATES IN A CHANGING WORLD}

Globalization has established new challenges for the interaction among nation states. The emergence of new powerful actors in the international system, such as multinational organizations, sub-national governments and a vast array of actors in the global civil society is making it harder for national states decide when and how they should proceed to national and international interventions. At the same time, cultural differences are emphasized as never before, forcing multicultural nation-states to strategize on how to handle such differences. If globalization brings with it "localized globalisms", using a term Boaventura de Souza Santos (2002) once used to refer to a type of homogenization of the global culture, it also brings about "globalized localisms", reiterating the presence of hegemonic cultures in many instances of the international society.

According to Huntington (1993), while these cultural shocks have existed even after the Peace of Westphalia, they were intensified by globalization. In fact, with this phenomenon "the world is becoming a smaller place [...] interactions between peoples of different civilizations are increasing; these increasing interactions intensify civilization consciousness and awareness of differences between civilizations" (Huntington, 1993, p. 25). The same author illustrates this argument with the consequences of cultural differences among the US, China, Japan and the European Union.

With the Cold War over, the underlying differences between China and the United States have reasserted themselves in areas such as human rights, trade and weapons proliferation. These differences are unlikely to moderate. A "new cold war," Deng Xaioping reportedly asserted in 1991, is under way between China and North-America. The same phrase has been applied to the increasingly difficult relations between Japan and the United States. Here cultural difference exacerbates economic conflict. People on each side allege racism on the other, but at least on the North-American side the antipathies are not racial but cultural. The basic values, attitudes, behavioral patterns of the two societies could hardly be more different. The economic issues between the United States and Europe are no less serious than those between the United States and Japan, but they do not have the same political salience and emotional intensity because the differences between North-American culture and European culture are so much less than those between North-American civilization and Japanese civilization (Huntington, 1993, p.34).

Besides cultural differences, globalization brings about changes in the basic characteristics of social and economic structures of the world-system. These post-industrial attributes emphasize the complexity of the international system in which nation-states interact.

This process is undoubtedly diverting the responsibility of the nation state in matters that previously were exclusively under its authority. Among these matters, absolute legitimacy to make economic interventions, power to promote political stability and major influence on nuclear weapons proliferation can be cited. These subjects are especially important in the case of the US, because this nation has the power to act on all of them, not only within its territory, but also in the international context. 
Table 1: Changes in the social and economic components of the world system from the pre-industrial to the post-industrial age

\begin{tabular}{|c|c|c|c|}
\hline & Pre-industrial & Industrial & Post-industrial \\
\hline Mode of Production & Extractive & Fabrication & $\begin{array}{l}\text { Processing, } \\
\text { Information }\end{array}$ \\
\hline Economic Sector & $\begin{array}{l}\text { Primary, } \\
\text { Agriculture, mining, } \\
\text { fishing, timber, oil } \\
\text { and gas }\end{array}$ & $\begin{array}{l}\text { Secondary, } \\
\text { Manufactured goods, } \\
\text { heavy construction }\end{array}$ & $\begin{array}{l}\text { Services Sector } \\
\text { Transportation, } \\
\text { utilities, trade, finance, } \\
\text { insurance }\end{array}$ \\
\hline Transforming Resource & $\begin{array}{l}\text { Natural power, } \\
\text { wind, water, draft, } \\
\text { animal, human } \\
\text { muscle }\end{array}$ & $\begin{array}{l}\text { Created energy, oil, } \\
\text { gas, nuclear }\end{array}$ & $\begin{array}{l}\text { Information and } \\
\text { knowledge; } \\
\text { programming and } \\
\text { algorithms; computer } \\
\text { and data transmission }\end{array}$ \\
\hline Strategic Resource & Raw materials & Financial capital & Human capital \\
\hline Technology & Craft & Machine technology & Intellectual technology \\
\hline Mode of Work & Physical labor & Division of labor & Networking \\
\hline Methodology & Trial and error & Empiricism & $\begin{array}{l}\text { Models, simulations, } \\
\text { decision theory }\end{array}$ \\
\hline Axial Principle & Traditionalism & Productivity & $\begin{array}{l}\text { Codification of } \\
\text { theoretical knowledge }\end{array}$ \\
\hline
\end{tabular}

Source: Curtis, 2009, p. 160.

On the economic side, for example, the US is without doubt the major source of influence worldwide. If we consider that this country is in the origin of the neoliberal economic model that emerged in the 1970s, with its economic principles mainly based on the prevalence of the private sector, financialization of the economy, free trade, deregulation and reduction of government spending, we can fast realize that its global significance is undeniable up to the present. The 2008 financial crisis reiterates the impact of the US on the globe. An internal mortgage crisis had the power and scale to shake the global financial market until today. With the collapse of Lehman Brothers, one of the major North-American banks, the crisis propagated worldwide and, according to The Economist (2013), "the effects of the crash are still rippling through the world economy". This fact raises some important questions: if the US was unable to control an internal crisis, how would it be able to control an international crisis? What was the true cause of the crisis, the North-American nation state, or the ethereal entity called "market", materially represented by a multinational corporation? What other international actors can have enough economic power to challenge or exceed the US capacity to influence the international system?

Regarding nuclear weapons control, the historical conflict between the West and the East represents another challenge for the interaction between nation states in the global arena. After the unparalleled use of atomic bombs by the US in the 
World War II, the use of such weapons entered the realm of possibilities. As a consequence, the West, under the leadership of this country, started to promote worldwide activism against further production and use of these armaments, to avoid similar calamities. According to Huntington (1993, p. 46): “The West promotes nonproliferation as a universal norm and nonproliferation treaties and inspections as means of realizing that norm. [...] The non-Western nations, on the other hand, assert their right to acquire and to deploy whatever weapons they think necessary for their security".

Even though the nuclear potential of the US is still the second biggest on earth (see Chart 1), only behind of Russia, the number of countries attempting to build nuclear arsenals doubled in the last 50 years (Forbes, 2014). Therefore, the possibility of future atomic threats is feasible, and even the US seems unable to control new attempts of nuclear escalation. The recent endeavor of North Korea to increase their nuclear program, with serious potential of a nuclear offensive in neighbor countries such as South Korea and China, is a case in point (The Economist, 2016). In this case, in the absence of a better option for the North-American government, the only plausible strategy seems to be missile defense, in co-operation with China, Japan and South Korea.

Chart 1: Nuclear arsenals, in warheads, by country in 2016

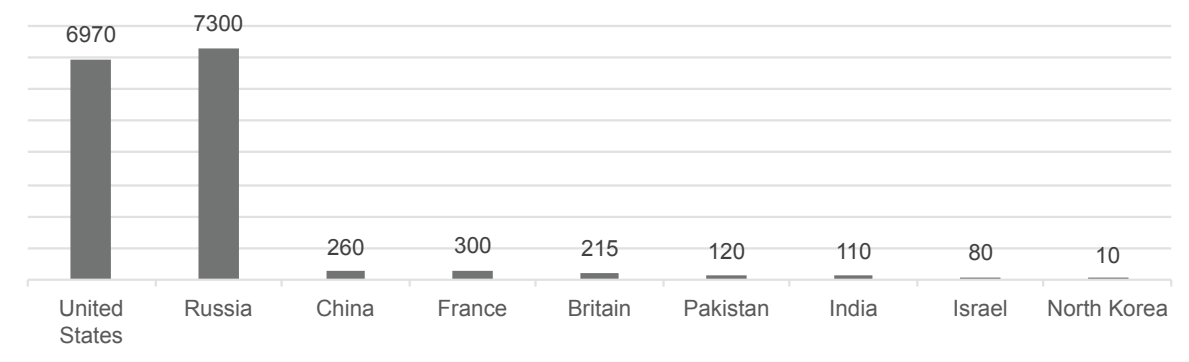

Source: Federation of American Scientists, 2016 and ICAN (2016); chart developed by the author.

Concerning the political power to stabilize the international system, evidence shows that the US does not seem so efficient as it was after the end of the World War II. In this sense, it may be losing legitimacy both in relation to other powerful countries and to new powerful international actors. In the former case, some authors claim that China would be in the way to replace the US in the global economic scenario (Arrighi, 2007), however with little interest to manage political matters. In the latter case, one can say that the growing power of international agents beyond the nation state can pose a real threat to the power and hegemony even of the most influential countries, such as the US. There is a growing literature showcasing the power of cities (Curtis, 2014, 2016), of multinational companies (Chesnais, 1996; Compa, 2014), of intergovernmental organizations, such as the World Bank (Collins and Rhoads, 2009), of religious organizations, of transnational criminal and terrorist groups and even of networks (Corbetta, 2013) in shaping international politics, in many cases supplanting the nation-state. 
Indeed, since the 1970s there are signs of the decline of the North-American world power (Wallerstein, 2004). The end of the Bretton Woods agreements, the petroleum crisis and the defeat in Vietnam are cases in point. September 11 and the 2008 financial crisis also showcase a relative weakness of the North-American empire (Wallerstein, 2004; Fernandes, 2015). Recently, one can also cite the Arab Spring that happened between 2010 and 2012, the Syrian civil war, happening since 2011 and the Russia-Ukraine tensions over the Crimea region, always existent but intensified in 2014, as situations in which the US had little power (or interest) to interfere. Had the US power to avoid, control or stop such tensions? Are all these conflicts a sign of the lack of a "powerful stabilizer" in the international system?

To analyze these issues it is worthy to revisit the theories of systemic cycles of accumulation and hegemonic stability, in an attempt to explore if the hegemonic role played by the US in the international system since the end of the World War II is still present.

\section{NORTH-AMERICAN CYCLE OF ACCUMULATION}

In his book The long twentieth century (Arrighi, 1994), Italian sociologist Giovanni Arrighi studied the evolution of Capitalism throughout history. Using Marx's concept of circulation of value through the money-commodity-money formula (MCM'), and based on Braudel's division of Society in three layers (material life, market economy and anti-market), Arrighi developed the concept of systemic cycles of accumulation.

According to the Marxist perspective, on these cycles there is a pattern of productive expansion followed by a financial expansion.

Marx's general formula of capital (MCM') can therefore be interpreted as depicting not just the logic of individual capitalist investments, but also a recurrent pattern of historical capitalism as world system. The central aspect of this pattern is the alternation of epochs of material expansion (MC phases of capital accumulation) with phases of financial rebirth and expansion (CM' phases). In phases of material expansion money capital "sets in motion" an increasing mass of commodities (including commoditized labor-power and gifts of nature); and in phases of financial expansion an increasing mass of money capital "sets itself free" from its commodity form, and accumulation proceeds through financial deals (as in Marx's abridged formula MM'). Together, the two epochs or phases constitute a full systemic cycle of accumulation (MCM') (Arrighi, 1994, p. 6).

In the course of the systemic cycle, two momentums must be distinguished: the transition from the material expansion to the financial expansion within each cycle, and the transition from one systemic cycle to another, or hegemonic transition. In the first kind of transition, Arrighi (1994) adopts the hypothesis of a downward trend in 
the long-term profit rate of productive/commercial activities. Such trend leads to a drastic reduction of profit margins, leading to a scenario in which "decreasing returns set in, competitive pressures intensify, and the stage is set for the change of phase from material to financial expansion" (Arrighi and Silver, 2001, p.262).

Furthermore, Giovanni Arrighi and Beverly Silver published a work with the central purpose of explaining the characteristics of the second kind of transition: Chaos and governance in the modern world system (Arrighi and Silver, 1999). Exemplified by the transitions from Dutch to British hegemony in the eighteenth century and from British to the US hegemony in the late-nineteenth century, the authors developed a model that illustrates the process of hegemonic transition. Figure 1 illustrates this model.

According to it, while the hegemonic state exercises its leadership in the international arena, two simultaneous processes occur: establishment of policies of general interest deepening the division of labor and specialization of functions, and escalation of other states in the path of development, emulating the hegemon's strategies firstly via cooperation, and then via competition (Fig.1, column 1). This scenario eventually leads to a hegemonic crisis, characterized by three processes: intensification of interstate and inter-enterprise competition, escalation of social conflicts and new configurations of power (Figure 1, column 2). Further evolutions in this situation eventually cause hegemonic "breakdown" and systemic chaos, typical of the advanced stages of financial expansion; this course entangles the emergence of new hegemonies (Figure 1, column 3). Finally, with the emergence of a new stabilizing state, the system is led to a new phase of co-operation among states and, again, emulation of the hegemon's development strategy; it is the start of a new hegemonic cycle (Arrighi and Silver, 2001).

Figure 1: The dynamics of hegemonic transitions.

\begin{tabular}{|l|l|l|l|}
\hline \multicolumn{1}{|c|}{ Hegemony } & \multicolumn{1}{|c|}{ Hegemonic transition } & New hegemony \\
\hline crisis & $\begin{array}{c}\text { Hegemonic } \\
\text { breakdown }\end{array}$ & \\
\hline $\begin{array}{l}\text { Systemic } \\
\text { reorganization } \\
\text { by hegemonic } \\
\text { state }\end{array}$ & $\begin{array}{l}\text { Interstate rivalries } \\
\text { \& inter-enterprise } \\
\text { competition }\end{array}$ & $\begin{array}{l}\text { Systemic chaos } \longrightarrow \text { Systemic reorganization } \\
\text { by new hegemonic state }\end{array}$ \\
$\begin{array}{l}\text { Eystemic } \\
\text { expansion } \\
\text { of the } \\
\text { hegemonic } \\
\text { state }\end{array}$
\end{tabular}

Source: Arrighi \& Silver, 2001, p.270. 
Following this pattern, Arrighi (1994) arguments that in the last 500 years, four world powers stood out for the building of production and accumulation chains: Genoa, United Provinces, Great Britain and the US. These political units became more powerful one after another, and except in the case of the last one, were replaced according to predictable historical pattern. This pattern consisted of a phase of productive economic expansion, followed by a phase of financial accumulation, and then decline. Table 2 summarizes the main characteristics of each systemic cycle.

Table 2: Main characteristics of each systemic cycle of accumulation

\begin{tabular}{|c|c|}
\hline Systemic Cycle & Characteristics \\
\hline Genoa & $\begin{array}{l}\text { - End of the XIII century and the mid-XVI century } \\
\text { - Main cities: Genoa, Milan, Florence and Venice } \\
\text { - Cultural industry as investment channel } \\
\text { - Loans to European governments, especially Spanish } \\
\text { - Decline of trade routes and hyper-accumulation crisis } \\
\text { - Alliance with Iberian governments in search of protection }\end{array}$ \\
\hline $\begin{array}{l}\text { United Provinces } \\
\text { (Dutch) }\end{array}$ & $\begin{array}{l}\text { - Beginning in the mid-XVII century } \\
\text { - Maritime expansion, piracy and plunder, large military capacity } \\
\text { - Precocious rentier class } \\
\text { - Oligarchic interests shocking with the government } \\
\text { - Amsterdam: central trading post and currency market } \\
\text { - At the end, expansion was limited by English and French Mercantilism }\end{array}$ \\
\hline Great Britain & $\begin{array}{l}\text { - Occurred between the XVIII and XIX centuries } \\
\text { - Large scale mercantilism } \\
\text { - Intra and extra European Imperialism } \\
\text { - Free trade and search for international competitiveness } \\
\text { - Absence of wars for territorial expansion, focus on overseas expansion } \\
\text { - Encouragement to decolonization and London as a financial center }\end{array}$ \\
\hline United States & $\begin{array}{l}\text { - Independence, territorialism and entrepreneurship } \\
\text { - Formation of large and dynamic internal market } \\
\text { - WWI and WWII contribute to productive and financial ascension } \\
\text { - Bretton Woods institutions support the imperial climb } \\
\text { - Transnational companies as central units of the world capitalist expansion }\end{array}$ \\
\hline
\end{tabular}

Source: the author, based on Arrighi, 1994.

In the case of the US, the productive expansion started right after its independence in 1776, with the incentive to migration to occupy the territory. This effort also built a huge and dynamic market of producers and consumers of industrial and agricultural goods. At the end of World War I, the US also had accumulated huge credits, especially from Great Britain. This event, together with the rise of the 
dollar as a major global currency, helped the country to accumulate immense amounts of capital. But it was only after the World War II that the country emerged as a major hegemonic power. The help to rebuild destroyed countries with the foundation of international organizations (e.g., FMI, BIRD, ONU), increasing military power, control of global finance and the emergence of the modern capitalist corporation, with "economies of speed and control of high technology" (Arrighi, 1994, p. 247) paved the way to the rise of the North-American global empire.

Thus, we can divide the North-American cycle of accumulation in three main phases: a) independence and territorial expansion; b) political and economic escalation after WW I and WW II and c) global financial expansion and "capitalism of corporations".

The US independence process, which occurred in 1776, was the initial fact that culminated in the rise of this country as a global power. Immediately after its independence, the country made a huge effort to expand the domestic market by encouraging migration. Those immigrants would compose both the group of producers of agricultural and industrial goods, and the consumers of those goods, all engaged in the exploration of the "new" territory. Hence, territorialist and capitalist logics were acting together in order to conform a large and dynamic territory, provided with entrepreneurs and consumers. This process of occupation of the new territory occurred at the same time that Britain was losing its strength as global hegemon, a process influenced by the German competition, the increased tariff protection and the end of the gold standard (Almeida, 1996).

Concerning the two world wars, the US was the main financer and acquired the most profits from both of them. Especially after the WW II, it also acquired huge political influence. If prior the WW I Britain was the largest US lender, this situation was basically reversed at the end of this war. At this time, "the US had repurchased for a bargain some of the massive investments that had built the infrastructure of its own domestic economy in the XIX century and, moreover, had immense credits accumulated" (Arrighi, 1994, p. 279). Moreover, at the end of the WW II, the US took the leadership of global governance. It helped to restore the Westphalian standard, through a policy of encouraging mutual assistance among nations and the reconstruction of the world. This was especially eminent in Europe, destroyed by both wars. It was based on this strategy that the IMF and the World Bank were founded. It is clear that after both of these conflicts the US took advantage of the situation, working to increase its global power and influence. Nevertheless, according to Arrighi and Silver (2001), three additional factors triggered the transition of the American cycle from material to financial expansion:

The tendency of competitive pressures on US corporations to intensify; the tendency of subordinate groups to claim a larger share of the pie; and the tendency of US corporations to hoard the profits of the material expansion in extra-territorial financial markets (Arrighi and Silver, 2001, p. 262). 
Hence, as stated in Arrighi (1994), a primary factor for the rise of the North-American empire was the modern capitalist company, which emerged in the US, with some existing features from the Dutch cycle. For him, the novel feature of capitalist companies in the North-American cycle was the internalization of transaction costs. This feature helped to raise capitalist enterprises to a standard of performance, profitability, scale of operations and range of territories never seen before. It was this pattern of companies, which later began to internationalize, becoming known as transnational corporations, that provided enough economic and financial basis for the North-American global supremacy.

Even though the systemic cycles of accumulation provide a useful framework of analysis for the North-American case, other theories were developed presenting additional perspectives on this topic, as it is the case of the theory presented in the next section.

\section{NORTH-AMERICAN HEGEMONIC POWER AND ITS EROSION}

In the 1970s, based on the works of Stephen Krasner, Robert Gilpin and Charles Kindleberger, especially in his book The world in depression, 1929-1939 (Kindleberger, 1986), it was developed the so called theory of hegemonic stability. It emerged from Kindleberger's studies of the causes of the 1929 crisis, mainly by his thesis that the depth, resilience and extension of the crisis were due to the lack of a clear international leadership, capable of stabilize and coordinate the world system (Mariutti, 2013). Hence, this theory supports the necessity of a global leader, responsible for regulating the market, keeping liberal values, providing credit and a strong currency, coordinating macroeconomic policies and maintaining a stable world environment, from a political-economic point of view (Kindleberger, 1996). In this sense, Great Britain in the second half of XIX century and the US since the post WW II are examples of global hegemonies.

There are two main approaches for the theory of hegemonic stability. The first is assigned to Kindleberger. According to it, the hegemon has a benevolent will, with the intension to keep liberal rules in the system, providing public goods (free trade and a monetary international system), being able to provide acyclic long-term loans and short-term financing in cases of crises. The second approach has a realistic nature, encompassing perspectives from Marxism and world-system, and is attributed to Gilpin and Krasner (Mariutti, 2013). It considers the egoistic nature of states, so that the hegemon would lead the international system mainly with the intention of self-benefit (Gilpin, 1987). 
Table 3: Main contributions of the authors who initially developed the theory of hegemonic stability

\begin{tabular}{|c|c|c|}
\hline Perspectives & Authors & Main Contributions \\
\hline Liberal & Kindleberger (1986) & $\begin{array}{l}\text { - Hegemonic stability is a public good, for being } \\
\text { 'non-exclusive' and 'non-competitive.' } \\
\text { - Three mandatory features for stability: 1) } \\
\text { maintenance of open market for imports, 2) } \\
\text { hegemon must provide long-term acyclic loans and } \\
\text { 3) short-term financing in times of crises. They can } \\
\text { be costly. }\end{array}$ \\
\hline \multirow[t]{2}{*}{ Realist } & Gilpin (1987) & $\begin{array}{l}\text { - It includes the idea of 'historic change' to } \\
\text { Kindleberger's concept of hegemony. } \\
\text { - It argues that historical change was driven over } \\
\text { time by the selfish nature of states. } \\
\text { - Countries are always looking to change the 'rules } \\
\text { of the game' for their own benefit. }\end{array}$ \\
\hline & Krasner (1976) & $\begin{array}{l}\text { - Study of the influence of hegemony in the } \\
\text { configuration of international trade structures. } \\
\text { - Relationship between hegemony and openness in } \\
\text { the international trade system, especially when the } \\
\text { hegemon is rising. }\end{array}$ \\
\hline
\end{tabular}

Source: the author, based on Cohen (2008).

This theory emerged in the 1970s, when the US was facing political and economic instabilities. Evidences of such situation were: decrease in relative participation on international trade, collapse of Bretton Woods system, end of the convertibility of the dollar in gold, instabilities in financial markets and in the balance of payments, 'free creation of currency' undermining confidence in the dollar and economic empowerment of Japan and Western Europe.

The evidence for hegemonic decline seemed obvious. In 1950, the United States accounted for a remarkable one-third of all world output of goods and services. Twenty-five years later, its share was less than one-quarter. In manufacturing the decline was even steeper, from nearly half the global total at midcentury to less than one-third by the 1970s. Overall, U.S. economic growth in the 1950s and 1960s was significantly below that of continental Europe and Japan. America's share of world trade dropped from some 33 percent in 1948 to less than 24 percent by the mid-1970s. In 1971, persistent balance of payments deficits forced Washington to terminate the convertibility of the dollar into gold, precipitating the collapse of the Bretton Woods system. By the 1970s it was clear that the country, once the world's greatest creditor, was rapidly becoming a net debtor. And where as recently as the 1950s the United 
States had been a net exporter of oil, it now appeared that the economy's continued access to energy resources had been placed in the unreliable hands of the Organization of Petroleum Exporting Countries (OPEC) (COHEN, 2008, p. 75).

All of these factors led some experts to conjecture about the end of the North-American hegemony (ARRIGHI, 1996; WALLERSTEIN, 2004). According to Wallerstein (2004), the decline of the US could be explained by four elements: the defeat in Vietnam, after huge financial and military investments; the revolutions of 1968, causing the defeat of the 'old left', that supported the imperialistic project of the US; the fall of the Berlin wall, putting an end to the 'common enemy' represented by communism; the September 11 attacks, representing both the dissatisfaction of the East with the North-American interference in the region, and the failure of the US in defending its own territory.

After those attacks, the well-known North-American interventions in Afghanistan and Iraq occurred, as forms of governmental counter-attacks on the Arab attempts to weaken the North-American power. Wallerstein (2004) points out that such counter-attacks brought about large military expenditure, at a time when the North-American economic situation was not the best. The author concluded that what was happening was just a repetition of a cyclical pattern of substitution of economic cycles, in which "the dominant power concentrates on the military side; the candidate for successor concentrates on the economic aspect" (Wallerstein, 2004 , p. 35), referring to the fact that at the time Japan was heavily investing in technology to support economic progress, while the US maintained an expensive support to the development of weapon technologies.

Another work that suggested the erosion of the North-American hegemony was the book After Hegemony (Keohane, 1984). Analyzing institutions, or "international regimes", that fomented transnational cooperation in the world political economy, the author argues that they are valuable mechanisms for promoting decentralized cooperation among nations. That is to say, the decline of hegemony, as the author understands North-American hegemony has vanished, does not make international cooperation impossible. Other important contribution in this respect was given by Snidal (1985), who analyzed different possible perspectives within the hegemonic stability theory. Even though the author does not directly advocate for the end of the North-American hegemony, he explores, for example, the possibility of "collective action" in a shared leadership of individual countries (i.e., not a single leader) supporting international cooperation.

Paul Kennedy's The rise and fall of great powers (Kennedy, 1988) also goes in this direction, pinpointing the relative decrease in the US share of the world production and trade from the 1960s onwards, the change of being the world's large creditor to becoming the large debtor, and the growth in military expenses, limiting the country's capacity to finance economic growth, as illustrations of America's "relative" fall. Mann (2004), evaluating four pillars of the North-American hegemony (military, economic, political and ideological), concluded that it 
became a "failed empire" and, in the long run, a "relative North-American decline will continue". Still according to the author, "the US is a military giant, an economic back-seat driver, a political schizophrenic and an ideological phantom. The result is a mess of contradictions, at first an incoherent empire - then a failed one" (MANN, 2004, p.650-2).

The master dissertations of Costa (2005) and Freitas (2006) represent additional works suggesting a decline in the US global power. According to Costa (2005), both the theses of the Political Economy of the World System (Wallerstein, 2004) and the crisis of the North-American global hegemony (Arrighi, 1994) present convincing arguments in favor of the North-American decline, particularly: the emergence of East Asia as a new global center of capital accumulation, the intense competition faced by the North-American corporations, and the US exorbitant trade deficit. Freitas (2006), by his turn, argues that the US is currently facing an hegemonic transition, triggered by the financial expansion prevailing from the late 1970s until the 1990s, but that currently shows signs of its exhaustion.

\section{COUNTER-ARGUMENT: THE “MYTH” OF LOST HEGEMONY}

Over the decades, some researchers expressed their disbelief in the decline of the North-American hegemony. A classic article in this regard is The Persistent "myth" of lost hegemony (Strange, 1987, p.564), according to which in the competitive game stablished between nations since the end of the twentieth century, "it is not relational power - described in conventional realist textbooks as the power of A to get B to do something it would not otherwise do - but structural power that counts". Therefore, the author argues that it is precisely the structural power that the US still "overwhelmingly" possesses. Four main aspects illustrate her argument: (a) regarding control and influence over international security, the US controls a powerful force of missiles carrying nuclear warheads, comparable only by the Russian forces; (b) the US still dominates the world's production structure of goods and services ${ }^{1}$; (c) it has the supremacy over the supply and availability of credit denominated in dollars, thus still exercises considerable influence in the world's monetary system; (d) it possesses the most influence over knowledge, being able to

\footnotetext{
${ }^{1}$ In this sense, Strange reiterates that the important variable to observe is not the share of industrial manufactured products nor the share of American exports of manufactures (which are indeed descending, as some authors in favor of the American decline argue), but the proportion of the world production of goods and services controlled by multinational corporations headquartered in the US. In the words of the author, “(...) The decision making power over the world's production structure still lies, not in Europe or Japan, but in the US" (Strange, 1987, p.568). However, if we observe the data presented in Carroll, Bloomfield and Maher (2014), we notice that between 2000 and 2014, the number of Fortune 500 Global Companies headquartered in the US has decreased by almost $30 \%$, while the number of companies participating in this list headquartered in China increased by astonishing $850 \%$.
} 
control the acquisition, communication and storage of knowledge and information in a global scale.

Cox (2007) also has an interesting view. Comparing the US with ancient empires, the author found many "similarities" that legitimize the use of the expression "North-American empire" up to the present. Among them: military capabilities, economic resources and many other structural advantages, as identified by Strange (1987). Moreover, the author discards the Chinese potential climb after "North-America's erosion," even though he does not exemplify how this country has demonstrated its "support" of the North-American position in Asia.

[...] China - an empire in the making (or so we have been told) that is bound to surpass the United States over the next twenty years. Yet this is not how it appears to the Chinese themselves who have done as much as any state could do over the past period to reassure Washington that it has no intention of challenging its position in Asia (Cox, 2007, p. 8).

On this subject, Leite (2005) contributed by examining the US foreign policy toward China, identifying a strategy of "containment for the engagement" justified by two reasons: the US desire to avoid the rise of an hegemonic power in Eurasia and the international system demand for long term stability. Thus, sheltered by a strategy of cooperation rather than confrontation among these states, the US hegemonic power remains. Krahmann (2005, p. 542) pinpoints that the US policies since September 11 "might not only be perceived as hegemonic, but also as imperialist within the context of neorealist theorizing", corroborating the perspective of Cox (2005).

In Brazil, a group of scholars also disagreed with the decline of the North-American power; amongst them one can cite Fiori $(2007,2008)$, Tavares (1985, 2004) and Serrano (2008). Fiori (2008) asserted that the floating dollar standard allowed the US to dominate the monetary and financial systems in a bigger scale than with the gold standard. Also, the US still has more control over technology and innovation, military power, production and control of information than any other country. Moreover, while criticizing Arrighi and Wallerstein fatalistic previsions of the "termination of the North-American empire" and even the end of the "modern world-system", Fiori (2007) argues that these authors failed because they considered the hypothesis that the international system requires a leader, or a "hegemon", to provide global governance. Therefore, according to Fiori, these authors fail to explain why global conflicts and competitive disputes among nations still happen, even with the presence of hegemons such as the US.

As stated in Tavares (1985), one of the reasons why the US was able to circumvent the 1970 crisis and acquire a pivotal role in the management of global finance was investing in the overvaluation of the dollar, converting the Federal Reserve (FED) in the main authority over the world banking system. Also in the context of the late 1970s, Tavares (2004) stated that, because the US had domain over the 'flexible markets' (dollar and petroleum), it did not need to bear with the burden 
of deregulation. Thus, it could act in the international system preventively or correctively whenever it wanted, even unilaterally, disregarding international organizations. Regarding the repercussion of the 2008 crisis for the "North-American empire", the argument of Serrano (2008, p. 164) is worth mentioning, "the 2008 crisis did not hurt the dollar as a global currency". Therefore, according to the author, the North-American empire still would have power to influence or control the main strategic factors necessary to manage the international system.

\section{CONCLUDING REMARKS}

Based on the discussions raised in the article, it is not clear if the North-American hegemony is indeed at the end. What the literature showcases is that the North-American power is steadily shrinking since the 1970s. This space of political and economic power is being filled by other powerful nation-states, particularly China (Arrighi, 2007). In addition, there is evidence that a number of other international actors are achieving more power in the international arena. Examples are the multinational corporations (Chesnais, 1996), global cities (Curtis, 2009, 2014, 2016; Mendes and Figueira, 2017) and even networks (Corbetta, 2013).

According to the theory of systemic cycles of accumulation, in the last 500 years, four world powers stood out for their building of production and accumulation chains. These nations became more powerful, and except in the case of the US, were replaced according to predictable historical pattern. This pattern consists of a phase of productive economic expansion, followed by a phase of financial accumulation and then finally decline. The current cycle is headed by the US because of its global hegemonic power. It formed the basis for the hegemonic stability theory, which was devised in the mid-1970s. This theory analyses the role of hegemons, such as the US, at the global level, and attempts to evaluate their positive and negative impacts.

Those theories help to explain the emergence and operation of world powers such as the US. However, neither of them is able to explain the current phase of the North-American hegemony. Some authors argue that the power of the US is declining since the 1970s, but the supremacy of this country in the global arena is still evident. Thus, even though evidences from both theories show that the North-American power is shrinking, they are unable to explain or predict if the North-American hegemony is de facto at its limit.

\section{REFERENCES}

ALMEIDA, P. (1996) “A economia mundial em perspectiva histórica”. Revista Brasileira de Política Internacional, v. 39, n. 2, p. 136-151.

ARRIGHI, G. (1994) The Long Twentieth Century: Money, Power, and the Origins of Our Times. Brooklyn, NY: Verso. 
ARRIGHI, G. (2007) Adam Smith in Beijing: Lineages of the Twenty-First Century. Brooklyn, NY: Verso.

ARRIGHI, G.; SILVER, B. (1999) Chaos and Governance in the Modern World System. Minneapolis, MN: U of Minnesota Press.

ARRIGHI, G.; SILVER, B. (2001) “Capitalism and world (dis)order”. Review of International Studies, v.27, p.257-279.

CARROLL, B.; BLOOMFIELD, K.; MAHER, M. (2014) The Changing Headquarters Landscape for Fortune Global 500 Companies. Bloomberg BNA Daily Tax Report, 2014. Available at: http:// www.ey.com.br/Publication/vwLUAssets/EY-the-changing-headquarters-landscape-for-fortune-global-500-companies/\$FILE/EY-the-changing-headquarters-landscape-for-fortune-global-500-companies.pdf. Accessed in May 8th, 2017.

CHESNAIS, F. (1996) A Mundialização do Capital. São Paulo, SP: Xamã.

COHEN, B. (2008) International Political Economy: An Intellectual History. New Jersey: Princeton University Press.

COLLINS, C.; RHOADS, R. (2010) “The World Bank, support for universities, and asymmetrical power relations in international development". Higher Education, v.59, p.181-205.

COMPA, L. (2014) "When in Rome: the exercise of power by foreign multinational companies in the United States." Transfer: European Review of Labor and Research, v.20, n.2, p.271-293.

CORBETTA, R. (2013) "International relations are about relations! The power of networks in the study of international politics." International Studies Review, v.15, p.637-640.

COSTA, J. (2005) Crise da hegemonia ou novo império Norte-Americano? Um confronto entre a Economia Política do Sistema-Mundo e a Nova Economia Política do Sistema Mundial. Dissertação (Mestrado em Economia) - Centro Sócio Econômico da UFSC. Universidade Federal de Santa Catarina, Florianópolis.

COX, M. (2007) "Still the American empire”. Political Studies Review, v.5, p.1-10.

CURTIS, S. (2009) Global Cities and the Transformation of the International System. London: ProQuest.

CURTIS, S. (2014) The Power of Cities in International Relations. London: Routledge.

CURTIS, S. (2016) "Cities and global governance: State failure or a new global order?" Millennium: Journal of International Studies, v.44, n.3, p.455-477.

FERNANDES, M. P. (2015) "Sobre o fim da hegemonia dos Estados Unidos: uma análise conceitual”. Meridiano 47 (UnB), v. 16, p. 3-10.

FIORI, J. L. (2007) “O “poder global.” Valor Econômico, October 10th, 2007.

FIORI, J. L.(2008) “O sistema interestatal capitalista no início do século XXI”. In: O Mito do Colapso do Poder Americano. Rio de Janeiro, RJ; São Paulo, SP: Ed. Record.

FORBES (2016). The nuclear weapons states - who has them and how many. Sep. 25th, 2014. Available at http://www.forbes.com/sites/jamesconca/2014/09/25/the-nuclear-weapons-states-who-has-them-and-how-many/\#15eea1af1fd1 Accessed in November 28th, 2016.

FREITAS, A. (2006) O Outono do Poder Americano. Dissertação (Mestrado em Economia) - Centro de Ciências Sociais Aplicadas da UFF. Universidade Federal Fluminense, Niterói.

GILPIN, R. (1987) The Political Economy of International Relations. Princeton: Princeton University Press.

HUNTINGTON, S. (1993) “The clash of civilizations?” Foreign Affairs, v.72, n.3, p. 22-49.

ICAN - International Campaing to Abolish Nuclear Weapons (2016). Nuclear arsenals. Available at http://www.icanw.org/the-facts/nuclear-arsenals/ Accessed in November 28th, 2016.

KRAHMANN, E. (2005) "American hegemony or global governance? Competing visions of international security". International Studies Review, v. 7, n. 4, p.531-545.

KENNEDY, P. (1988) The Rise and Fall of Great Powers. New York: Random House.

KEOHANE, R. (1984) After Hegemony: Cooperation and Discord in the World Political Economy. Princeton, N.J.: Princeton University Press.

KINDLEBERGER, C. (1986) The World in Depression, 1929-1939. Berkeley: University of California Press. 
KINDLEBERGER, C. (1996) World Economic Primacy: 1500 - 1990. Oxford: Oxford University Press.

KRASNER, S. (1976) "State power and the structure of international trade". World Politics, v.28, n.3 (April), p.317-47.

LEITE, D. (2005) A Política Externa dos Estados Unidos para a China: Contenção pelo Engajamento. Dissertação (Mestrado em Ciência Política) - Centro de Filosofia e Ciências Humanas da UFPE. Universidade Federal de Pernambuco, Recife.

MANN, M. (2004) “The first failed empire of the 21st century.” Review of International Studies, v.30, p.631-653.

MARIUTTI, E. B. (2013) "Política internacional, relações internacionais e economia política internacional: condições de diálogo”. Texto para Discussão (Campinas), v. 218, p. 1-49.

MENDES, M. V. I.; FIGUEIRA, A. R. (2017) "Paradiplomacy and the international competitiveness of cities: the case of Rio de Janeiro". Revista Brasileira de Politica Internacional, v.60, n.1, p.1-19.

SERRANO, F. (2008) "A economia americana, o padrão dólar flexível e a expansão mundial nos anos 2000". In: O Mito do Colapso do Poder Americano. Rio de Janeiro/São Paulo: Ed. Record.

SNIDAL, D. (1985) “The limits of hegemonic stability theory.” International Organization, v.39, n.4, p.579-614.

SOUZA SANTOS, B. (2002) A Globalização e as Ciências Sociais. São Paulo: Cortez Editora.

STRANGE, S. (1987) "The persistent myth of lost hegemony". International Organization, v.41, n.4, p.551-574.

TAVARES, M. C. (1985) “A retomada da hegemonia norte-americana”. Revista de Economia Política, v.5, n.2, p.5-15.

TAVARES, M. C. (2004) “O poder americano depois de 1970”. Folha de São Paulo, June 20th, 2004.

THE ECONOMIST (2016). Crash course. September 7th, 2013. Available at http://www.economist. $\mathrm{com} /$ news/schoolsbrief/21584534-effects-financial-crisis-are-still-being-felt-five-years-article Accessed in November 27th, 2016.

THE ECONOMIST. (2016) A nuclear nightmare. May 28th, 2016. Available at http://www.economist. com/news/leaders/21699445-it-past-time-world-get-serious-about-north-koreas-nuclear-ambitions-nuclear Accessed in November 28th, 2016.

WAllersteIN, I. M. (2004) O Declínio do Poder Americano: os Estados Unidos em um Mundo Caótico. Rio de Janeiro, RJ: Contraponto. 